Article

\title{
Can Leadership Transform Educational Policy? Leadership Style, New Localism and Local Involvement in Education
}

\author{
Nivi Gal-Arieli ${ }^{1}$, Itai Beeri ${ }^{1} * \mathbb{C}$, Eran Vigoda-Gadot ${ }^{1}\left[\right.$ and Amnon Reichman ${ }^{2}$ \\ 1 School of Political Sciences, University of Haifa, Haifa 3498838, Israel; galarieli@gmail.com (N.G.-A.); \\ eranv@poli.haifa.ac.il (E.V.-G.) \\ 2 Faculty of Law, University of Haifa, Haifa 3498838, Israel; reichman@law.haifa.ac.il \\ * Correspondence: itaibeeri@poli.haifa.ac.il; Tel.: +972-4-828-8681
}

Received: 23 September 2020; Accepted: 10 November 2020; Published: 17 November 2020

\begin{abstract}
In the realm of new localism and collaboration, local educational policymakers are called upon for responsible community leadership. Given the conceptual continuum between new localism and transformational leadership, this study examines the relationship between the leadership style of local educational policymakers and the involvement of local authorities in education. Data were obtained from 107 questionnaires submitted by mayors and directors of education affiliated with 100 local authorities in Israel. As predicted, there was a positive relationship between transformational leadership and the local authorities' involvement in education, measured using four factors, but only for sound local authorities. We used five criteria to determine the soundness of the local authorities. In contrast, among less sound local authorities, there was an inverse relationship between transformational leadership and involvement in education. In general, in such communities, leaders seemed to prefer to leave educational issues to the central government. Thus, we present evidence for the boundaries of educational transformational leadership in the educational governance arena. Education-related policies are on the agenda of leaders even in weaker local authorities, but only to the extent that these policies can serve as an instrument to meet specific needs of the local community. All in all, there is no "one size fits all" for all aspects of new localism-i.e., central regulation towards local government, local policy, local leadership, and civic participation. Accordingly, policymakers, local leaders and residents must fit themselves to the blurred boundaries of new localism and collaborate towards better education. Implications of the findings are discussed.
\end{abstract}

Keywords: new localism; educational policy making; educational community leadership; involvement in education; local governance; transformational leadership; local government; educational governance; Israel

\section{Introduction}

Koppich and Esch [1] asked "Who Shapes Teacher Policy?" They examined the shift of some educational decision-making authority from the states and the federal government to powerful extra-governmental actors-the business community and philanthropic foundations. We take a different approach to this question by reexamining how responsibility for various aspects of public policy should be allocated between the central government and other organizations, including local authorities. This approach accords with similar trends in the areas of health and social welfare [2]. Simultaneously, policymakers have increasingly sought to involve the public in policy design in various fields [3]. In contrast to the local government's simply carrying out the mandates of the 
central government, one outcome of this twofold development has been the large-scale transfer of responsibility for public services to local authorities, particularly mayors [4]. The rationale for this change is that local leaders are best placed to understand the needs of their communities and to adjust services accordingly.

In this vein, Bovaird and Löffler [5] suggest that local players should go one step further-beyond the traditional improvements in service delivery-towards "good local governance." Measures of such good local governance include collaboration, engagement and collective action by multiple stakeholders and the local leadership in pursuit of smart solutions to collective problems [6-9], including education [10]. We define this approach, referred to as new localism, as the empowerment of local authorities based on values such as accountability, civic participation, equality, and collaboration between key local players [11,12]. In the realm of education specifically, Stone-Johnson [13] called for responsible community leadership that relies on the strength of the relationship between schools and communities [14]. In addition, Hicks [15] recently found that local educational policy is mediated through profoundly political factors at a much more local level than is often considered.

Similar principles characterize transformational leadership-a leadership style that has likewise gained ground in recent decades as a theory of public policy [16-18]. The vision of transformational leadership is of a society in which individuals demonstrate personal responsibility while pursuing goals that advance the interests of the group. More specifically, transformational leaders identify the underlying needs and interests of the group, develop a vision for meeting those needs, and then inspire group members to cooperate in taking responsibility for the design and implementation of policy [19]. As such, the concept of transformational leadership coincides neatly with the demands and opportunities of new localism.

One of the common focal concepts of new localism and transformational leadership is social capital-a concept used by Putnam [20] to explain the value of non-material assets held by a community, including the community's ability to maintain internal collaborations and initiatives aimed at self-promotion and development. Putnam defines social capital as "features of social organization, such as trust, norms and networks, that can improve the efficiency of society by facilitating coordinated actions" ([21], p. 167). Social capital refers to the complex web of relationships, shared norms and values, trust, and other resources within a community that enable its members to cooperate for the common good. Transformational leadership and new localism are alike in that both highlight the importance of this collective efficacy and capacity for self-promotion, collaboration, participation in decision making, and commitment to change [22-24]. In the field of education, scholars of both education and localism [25-28] and transformative leadership in education emphasize the role of social capital in improving communal life locally and in the broader social context within which it is embedded [29-34]. Indeed, the interplay among the three concepts may be even deeper, with transformational leaders helping to promote and strengthen localism by both exploiting and developing local social capital.

To the best of our knowledge, this is the first study that explores the relationship between transformational leadership in education, educational governance-at the municipal rather than the more commonly studied school level [23] —and new localism on the ground, in terms of the policies that local authorities actually promote and implement. Specifically, we use a survey of 107 local leaders (mayors and heads of local education departments) along with publicly available data to relate the leadership style of educational policymakers in Israeli local authorities to the emergence of new localism, expressed as the increased involvement of local authorities in the realm of education. We chose education as the context for the study because of its unique role in building local communities and promoting social change.

The main contribution of the article, beyond its empirical contribution, is to illuminate an emerging line of research, one still in its infancy, on local social capital as an input into the local educational system, which is one of the pivotal realms of local responsibility. We propose that in the era of local governance and new localism, municipal policymaking that features the investment of social capital in local education is as likely to bear fruit as investment in other types of infrastructure [35]. However, 
for the same reasons, at the national level, investment in local social capital may also increase the socioeconomic and educational gaps between communities and local authorities.

The article is divided into three sections. In the first section, we introduce the concepts that form the theoretical infrastructure in the context of educational policies and the transformational leadership style. The second section describes the research methodology and presents the study's findings. In the third section we discuss the implications of the main findings. We discovered that the adoption of a transformational leadership style promoted involvement in education in relatively sound local authorities, but deterred and reduced involvement in education in weaker ones.

\section{Localism and Education-the Research Model and Hypotheses}

\subsection{Localism and Education}

In recent decades, new localism has established itself throughout Europe, the United States, Australia, Israel and other countries that are influenced by Western culture and politics $[25,28,36,37]$. According to Coaffee [38], the phenomenon has its roots in the discussion introduced by Giddens [39], who proposed a "third way" for public policy, based on market economy principles but with the option of government intervention when deemed necessary. To some extent, new localism can be traced to the recognition of the tension between a tendency toward centralization and democratic values such as accountability, subsidiarity, equality and civic participation $[2,11,38,40]$.

De Vries [40] (p. 197) notes that the novelty of new localism is not the transfer of services to the local level per se, but rather the reasoning behind it. What is new in new localism is the claim that the local authority is better suited to listening to the people, not just a better vehicle for providing public services because of its greater flexibility.

This development is especially noteworthy in light of two intertwined sets of policy ideas that have dominated educational reform in recent years: markets and accountability [37,41]. The first involves the opening of public schools to private, nonprofit and philanthropic agendas and involvement. The second leads to the pursuit of standardization in the educational system, evident, for example, in the uniform standards set by the OECD (Organization for Economic Co-operation and Development) for educational achievement around the world. Accordingly, nations have tried to raise their students' achievement and their position in international rankings. To do so, they have sought solutions to a large-scale, national challenge [42,43]. The importance that countries attach to international indices filters down to the local authorities, communities and entrepreneurs. These groups-not necessarily parents—seek to increase students' achievement according to the same standards [30,41,44].

In Israel, the Compulsory Education Law (1949), Section 7(b) [45], divides responsibility for education between the Ministry of Education and local authorities in an ambiguous manner: "Official educational institutions for the provision of free elementary education under this Law to children and adolescents resident in the area of jurisdiction of a particular local education authority shall be maintained by the State and the local education authority jointly ... " To clarify this undefined "joint maintenance" of educational institutions, various laws, ordinances and regulations were passed that sought to demarcate more explicit lines of authority and responsibility between the Ministry of Education and local government authorities. Against this backdrop, for many years the educational system in Israel was extremely centralized. The Ministry of Education had exclusive control over setting educational policy, determining curricula, employing teachers and supervising their work. Since the 1980s, this situation has gradually changed, as Israel, like other nations, has seen local authorities become increasingly involved in education. At the same time, the Ministry of Education has gradually withdrawn its influence from the design of educational policies [46].

Laws and regulations passed over recent decades have created interactions between the Ministry of Education, the local authority and the local community in various areas, including the four that we chose to examine: the designation of school catchment areas, the opening of new schools, the introduction of new curricula and the direct employment of teachers. 


\subsection{Transformational Leadership and New Localism}

In the conceptual system of Burns [18] and Bass [16], transformational leadership is distinct from transactional leadership, in which the leader promotes compliance by means of reward and punishment. A transformational leader inspires followers to take responsibility on the basis of identification with and commitment to a common goal. Transformational leaders get things done by conceiving and communicating a compelling vision that addresses and then exceeds group members' immediate needs $[16,18]$.

The notion of transformational leadership owes much to the organizational behavior literature, which supports the ability of transformational leadership to foster community-oriented processes of change [16-18]. Numerous studies have documented a positive relationship between transformational leadership and employee performance (e.g., [47]). Putnam [20], in his well-known work on community and social capital, considers transformational leadership a prerequisite for social change. He draws on the ideas of Bass and Burns to describe transformational leaders as those able to recruit local residents to engage in activities that advance the interests of the community. Recently, scholars such as Shields $[33,34]$ have connected social capital with transformative leadership in the education field, stressing the success of individuals and organizations as a whole in addressing issues related to justice and democracy. According to her view, educational leaders' taking action is necessary as a response to the current state of society, which is volatile, uncertain, complex and ambiguous.

As noted previously, essential to new localism is the ability of citizens to voice their wishes in order to influence the community in which they live. As such, there is a conceptual continuum between the principles of new localism and the principles of transformational leadership. New localism is grounded in the idea that the smaller political framework of the local authority is better suited to the values that characterize the current approach to public policy, values that include transparency, equity, and civic initiative. These same values underlie transformational leadership, which engages members of the community or group in shared responsibility and collaboration with stakeholders with the goal of problem-solving and improving performance $[19,23,24]$. Accordingly, organizational social capital can translate transformational educational leadership into new localism. Exchanging, borrowing and leveraging resources, building trust, and maintaining multiple interactions of shared decision-making and collective action eventually enhance communal support, knowledge, information, wisdom, and expertise that, in turn, can achieve instructional goals, overcome obstacles, improve school conditions, and foster innovation and student achievement [48,49].

How this works in practice can take many forms. For example, imagine that a local director of education who uses a transformational style of leadership wishes to involve the community in revamping parts of the school curriculum. The director might create a roundtable on "The Future of Local Education-How to Prepare for 2030" to which local stakeholders (including but not limited to parents) would be invited. The roundtable would draw on the participants' expertise and experience, while the director's transformational leadership would facilitate the give-and-take needed to develop relationships, shared values and trust. Ultimately, the roundtable might produce a call to include multicultural themes in the curriculum.

Education may play a unique role in new localism (e.g., [50]). Kerr, Dyson and Gallannaugh [51] note that stronger school-community relations have typically been regarded as desirable. In a similar vein, Crowson and Goldring [25] argue that education's inherent ability to preserve and inculcate values over the generations makes it the most important social instrument available to policymakers. At the same time, through school governance and by coordinating teachers, students and residents [52,53], schools and educational leaders can integrate the community. They can serve as a central gathering place for the community, providing a podium for voicing concerns and promoting the values desired by all citizens, not only the young people educated there [54]. For Wei $\beta$ [28], localism, at its best, develops community through the schools, rather than developing schools as separate communities.

Given the centrality of schools as local institutions and instruments of social change, it seems likely that the degree to which local education policymakers (council heads/mayors and heads of 
education departments) adopt a transformational leadership style will affect the degree of the local authority's involvement in education. Hence, we expect that:

Hypothesis 1 (H1). The more the leadership style of local leaders (mayors and heads of local education departments) coincides with the transformational approach, the greater will be the local authority's involvement in the realm of education.

\section{The Soundness of Local Authorities and Their Involvement in Education}

We define the soundness of a local authority as the accumulation of various attributes and factors that enable the local authority to realize the objectives it has set for itself [55]. Based on the findings of previous studies, in Israel sound local authorities are those that are large, have financial strength, enjoy a high level of socioeconomic status, are geographically close to the center of the country and are populated by the national majority [36]. Consistent findings in all Western countries point to a clear correlation between academic achievement and students' socioeconomic background [56-58]. Population groups that are strong in terms of their socioeconomic and cultural background do better on the official instruments used for assessment and measurement. Thus, children from strong communities do better on standardized tests than do children from weak communities [57]. The sad result is that the gaps between strong and weak communities are maintained and preserved. Those who in the previous generation belonged to strong population groups hold the keys to success and pass them on to their children, handing down social power from generation to generation.

In this vein, education can play a critical role in creating local social capital and promoting the interests of a community rather than only those of individual children and their parents [59]. Interestingly, this pattern holds in other directions as well. For example, Postholm [60] reports that some teachers see the school as being very accountable to the local authority. In addition, Balfanz et al. [44] report on the benefits of recruiting non-professional forces to raise the achievement of students in certain areas. Projects in which businesses, NGOs and volunteers collaborate to strengthen educational institutions and improve students' achievement have been fruitful. However, the fundamental condition for the success of such educational reforms is based primarily on civic capacity, local collaboration and the ability to recruit authentic, committed and beneficial local forces-above and beyond traditional bureaucratic stakeholders - that share mutual trust [30,41]. This is where localism can come into play.

Hodgson and Spours [26] suggest a distinction between authentic or democratic localism and localism that is imposed from above by the central government. Democratic localism refers to the movement of power and resources away from central control and towards local democratic structures, managers, communities and local consumers, within an agreed-upon national framework. Imposing new localism from above raises the concern that not all communities have the resources and capabilities needed to cope with complex challenges at the local level, leaving them threatened by mergers, loose networks, fuzzy control and corruption [61,62]. Democratic localism, a grassroots phenomenon that makes room for the self-expression of local powers, is based on two pillars: cooperation between local stakeholders and encouragement of the local grassroots voice.

Essuman and Akyeampong [36] point out that the creation of authentic localism depends on the central government's ensuring sufficient economic and social conditions. They warn against the use of localism as a means for the central government to avoid its own obligations, while ignoring the differences between one local authority and another. In other words, while the politics of centralism seeks to tightly control and change the extent and depth of state intervention, the politics of localism promotes decentralization, distributing power to the civic society, social groups and individuals. Wei $\beta$ [28] notes that the central government would gladly champion localism, but only to lighten its burden of responsibility. However, not all local authorities have the same resources, potentially creating gaps in their ability to independently ensure a satisfactory level of education. In such cases, 
instead of leading to the development of active, independent localism, the results could be far more problematic $[28,56]$. This raises the question: how might the strength of the local authority affect the relationship between transformational leadership and the local authority's involvement in education?

Empirical studies, both in Israel and throughout the US and the world, have demonstrated differences not only in educational outcomes [2], but also in the willingness of local authorities and mayors to balance their agenda setting and to involve the local authority in issues pertaining to education. Many of these differences are related to the local authority's level of preparedness [63]. The main factor, of course, is the local authority's financial health $[36,64]$. This is only logical, as wealthier local authorities can provide higher-quality services. They can fund new, technologically advanced facilities or hire more and better-qualified teachers to reduce class sizes or increase the number of subjects taught $[65,66]$. Other factors that have direct or indirect effects on the local authority's involvement include its size (in terms of population), its geographic location (its distance from economic and cultural centers), and the socio-demographic characteristics of the local population $[36,63]$.

Hence, our second hypothesis is that the soundness of a local authority moderates the relationship between a transformational leadership style and the involvement of the local authority in education:

Hypothesis 2 (H2). In sound local authorities, a stronger relationship is expected between transformational leadership and the local authority's involvement in education, as compared to the relationship in relatively weaker local authorities.

Our research model and hypotheses are depicted in Figure 1.

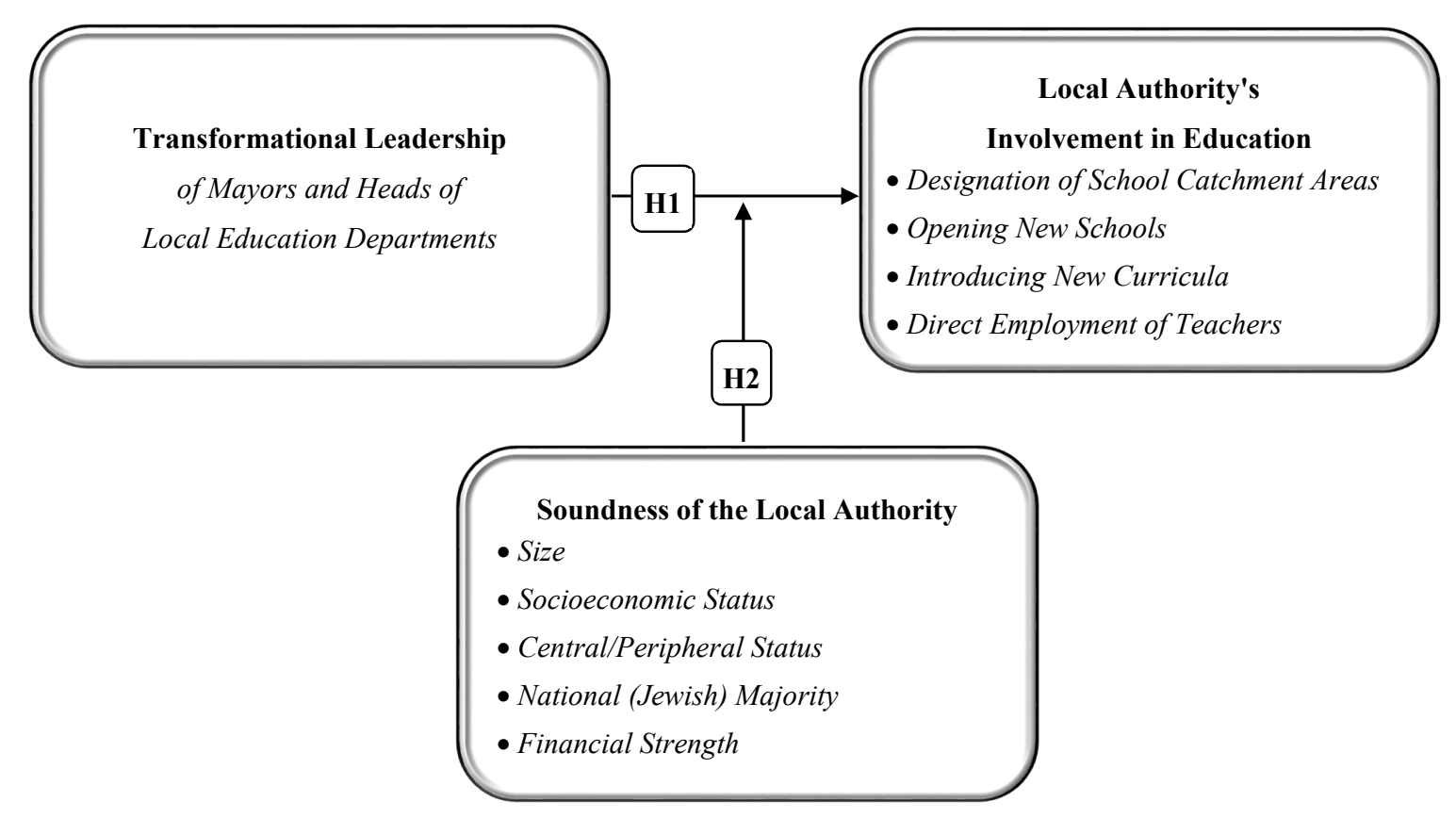

Figure 1. Research model and hypotheses.

\section{Method}

\subsection{Research Procedure, Data Collection and Sampling}

The focus of the investigation was local authority leaders' perceptions of their authorities' involvement in education, and a self-report about their leadership styles. We created a questionnaire specifically for this purpose. We also used publicly available data produced by Israel's Interior Ministry and Central Bureau of Statistics to assess the soundness of the local authorities. 
The questionnaire was sent to all 254 local authorities in Israel, in duplicate, with one copy intended for the mayor and the other copy for the head of the local education department. Each questionnaire was marked with the name of the official who was the intended recipient. A total of 107 questionnaires were returned from 100 local authorities (seven local authorities returned two questionnaires each), constituting a return rate of $42 \%$. Of the respondents, $37 \%$ were heads of education departments and $63 \%$ were mayors.

As part of a preliminary stage of the study, we conducted 16 in-depth, semi-structured interviews with local officials in key positions related to policymaking in education. Specifically, we interviewed the head of a local authority; a district director at the Ministry of Education; two directors of divisions in the Ministry of Education; two former directors of divisions in the Ministry of Education; an elementary school principal; two former school principals, who currently hold key positions-one in the Ministry of Education and the other in the Education Division of a local authority; a legal adviser to the Ministry of Education; a legal adviser to a local government Education Division; and a journalist and editor dealing with social affairs and education. We used convenience sampling as well as snowball sampling to gain reach and insights into local educational policy and local leadership, to finalize the conceptualization and research model, and to clarify and validate the questionnaire. Accordingly, each interview was divided into two parts. In the first part, we asked the interviewees to tell about their work and the relationship between the Ministry of Education and the local authority-from their point of view and based on their experience. Based on their responses, we adapted and fine-tuned the questionnaire. In the second stage, we asked the interviewees to talk about education as a public service, its nature and the factors that indicate the local authorities' role and involvement in local education. Both parts helped create the design of the questionnaire. As the interviews progressed, interviewees were asked to comment on parts of the questionnaire, and the various questions were refined accordingly. The interviews took place in the respondents' offices. Each lasted for about an hour and was documented with the permission of the interviewee.

\subsection{Research Tool and Variables}

\subsubsection{Dependent Variable-Involvement in Education}

In line with the developments in localism and education described above, we chose four domains of involvement in education in which the local authority's responsibility can be clearly examined:

- Determination of catchment areas (a responsibility granted to the local authority upon approval of the district administration).

- Establishment of new schools (doing so is under the authority of the Ministry of Education, but the Ministry is required to consult on the matter with the local authority).

- Instituting new curricula (doing so requires the approval of the Minister of Education, but the local authority is authorized to propose, opine on, and fund such changes).

- Employing teachers (while elementary teachers are employed by the Ministry of Education, the local authority may finance extra staff).

Participants were asked to indicate the degree of their local authority's involvement in each of these facets of local education on a Likert-type scale, ranging from 1 (very little involvement) to 3 (a great deal of involvement). An "overall involvement in education" variable was constructed for each respondent by calculating the average score for all items.

\subsubsection{Independent Variable-Transformational Leadership}

This variable was defined as the degree to which respondents assessed their own leadership style as tending towards the transformational style. We measured this factor using eight questions drawn from Bass's Multifactor Leadership Questionnaire [16]. The questions used capture four dimensions: idealized influence, inspirational motivation, intellectual stimulation, and individualized consideration. 
Participants were asked to indicate, on a scale ranging from 1 to 5 , the degree to which they identified with statements that represent transformational leadership behaviors. Sample statements include: "I treat each and every employee as an individual with unique needs, abilities, and aspirations;" "I go beyond personal interests and act to promote the institution that I lead and represent;" "I am looking for different points of view when troubleshooting;" "I emphasize the importance of a strong sense of mission" and "I stress the importance of a sense of common mission."

\subsubsection{Moderating Variable-Soundness of the Local Authority}

We defined this variable as the accumulation of various attributes and factors that enable the local authority to realize the objectives it has set for itself [55]. Previous studies have shown that the following factors increase the ability of an Israeli local authority to initiate and implement policies that work in tandem to improve the performance of the municipality: (i) a large population; (ii) a high socioeconomic status among residents; (iii) closeness to the country's central business and cultural zones; (iv) mainly populated by the national (Jewish) majority; and (v) local financial strength (as assessed by the Ministry of the Interior) [36,65]. In our sample of 100 local authorities, the average population was $28,100(\mathrm{SD}=37.4)$, and the average socioeconomic and central/peripheral levels were $5.76(\mathrm{SD}=2.13)$ and $5.58(\mathrm{SD}=1.88$ ), respectively (both on a scale from the Central Bureau of Statistics ranging from 1 (low) to 10 (high)). Seventy-seven percent of the communities were comprised largely of Jews, and $38 \%$ were financially strong.

All five scores were coded from 1 (least sound) to 10 (most sound). The average of the five parameters was weighted and calculated to construct an overall soundness variable for each local authority examined, which was $2.9(\mathrm{SD}=1.50)$ for the sample as a whole. All data were drawn from publicly available records from the Ministry of the Interior and the Central Bureau of Statistics.

\subsection{Statistical Analyses}

Responses to the questions were gathered and analyzed using the software programs SPSS 23 and SAS 9.4. We conducted a univariate analysis of all of the quantitative data, meaning the responses to the questions and the officially published data. We assessed the internal consistency of the research variables using Cronbach's alpha. We then conducted a bivariate analysis using Pearson's test to examine correlations between the continuous variables. Finally, a multivariate analysis was conducted using a stepwise linear regression.

\section{Findings}

Table 1 presents the means, standard deviations, and correlation coefficients for the research variables and Cronbach's $\alpha$ for the responses to the questionnaires. The interviewees pointed out the growing role and involvement of the local authorities in local education. If in the past education policy was set by the Ministry of Education alone, and local authorities simply implemented it, since early 2000 , those in charge of education in the local authorities have played a major role in determining local educational policy. For example, they have hired principals for the schools and adjusted the methods for determining catchment areas. The interviewees maintained that students, parents, teachers, managers and the community as a whole expect mayors and heads of local education departments to transform local education. The interviewees highlighted two factors in explaining this change. The first is the pressure of public opinion. Residents want quality education for their children and increasingly expect that the local authority, which handles all of their other affairs, will take care of education as well. The second is the trend toward decentralization, which has transferred responsibility from the Ministry of Education to local stakeholders. 
Table 1. Multiple correlation matrix and descriptive statistics for the research variables (Cronbach's $\alpha$ in parentheses).

\begin{tabular}{|c|c|c|c|c|c|c|c|c|c|c|c|c|c|c|}
\hline & Mean & S.D. & 1 & 2 & 3 & 4 & 5 & 6 & 7 & 8 & 9 & 10 & 11 & 12 \\
\hline 1. Transformational leadership & 4.5 & 4 & $(0.82)$ & & & & & & & & & & & \\
\hline 2. Size & 28.1 & 37.4 & 12 & $(-)$ & & & & & & & & & & \\
\hline 3. Socioeconomic status & 5.7 & 2.1 & 0.01 & -0.01 & $(-)$ & & & & & & & & & \\
\hline 4. Central/peripheral status & 5.6 & 1.9 & 0.22 & $0.43^{* *}$ & $0.27^{* *}$ & $(-)$ & & & & & & & & \\
\hline 5. National (Jewish) majority & $(-)$ & $(-)$ & 0.02 & 0.14 & $0.60 * *$ & 0.19 & $(-)$ & & & & & & & \\
\hline 6. Financial strength & $(-)$ & $(-)$ & 0.12 & 0.14 & $0.30 * *$ & 0.16 & $0.37^{* *}$ & $(-)$ & & & & & & \\
\hline 7. Overall soundness & 2.9 & 1.5 & 0.08 & - & - & - & - & - & $(-)$ & & & & & \\
\hline 8. Designation of school catchment areas & 2.14 & 0.47 & -0.03 & $0.25 *$ & -0.21 * & 0.03 & -0.14 & -0.08 & -0.06 & $(0.32)$ & & & & \\
\hline 9. Opening new schools & 1.90 & 0.50 & 0.04 & 0.15 & -0.03 & $0.27^{*}$ & 0.03 & -0.04 & 0.18 & 0.08 & $(-)$ & & & \\
\hline 10. Introducing new curricula & 2.53 & 0.58 & 0.11 & $0.23 *$ & 0.17 & 0.17 & 0.03 & $0.30^{* *}$ & $0.22 *$ & 0.15 & -0.11 & $(0.75)$ & & \\
\hline 11. Direct employment of teachers & 2.41 & 0.91 & -0.18 & 0.16 & 0.10 & 0.21 & $0.34^{* *}$ & -0.02 & 0.16 & -0.07 & -0.01 & 0.20 & $(-)$ & \\
\hline 12. Overall involvement in education & 2.25 & 0.40 & 0.03 & $0.35^{* *}$ & 0.07 & $0.29^{* *}$ & 0.09 & 0.14 & 0.23 * & - & - & - & - & $(0.75)$ \\
\hline
\end{tabular}


The analysis did not find a significant positive relationship between transformational leadership style and overall involvement of the local authority in education $(\mathrm{r}=0.03, p=$ N.S.) or any of the dimensions of the dependent variable (designation of school catchment areas, opening new schools, introducing new curricula, and direct hiring of teachers; $r=-0.03,0.04,0.11$ and -0.18 , respectively, $p=$ N.S.) (see Table 1). In other words, Hypothesis 1 was not confirmed.

However, when these relationships were reexamined with the moderating factors taken into account (soundness of the local authority, its size, socioeconomic status, central/peripheral status, sector, and financial strength), a significant relationship between transformational leadership and the local authorities' involvement in education emerged. Thus, under some conditions, Hypothesis 2 was confirmed. The results are shown in Tables 2 and 3 and Figure 2.

The findings confirmed the basic hypothesis that a transformational leadership style is positively associated with the increased involvement of the local authority in education, but only in relatively sound local authorities. The models that supported the hypothesis related to the opening of new schools (Models 1-3), the introduction of new curricula (Models 4-6), and overall involvement in education (Models 8 and 9). In relatively weak local authorities, an unexpected relationship (Model 7) emerged between transformational leadership style and greater involvement in the designation of school catchment areas. With regard to the hiring of teachers, none of the models was significant. The implications of the findings will be discussed in the next section.

Table 2. Hierarchical regression analyses for the relationship between transformational leadership and the local authority's involvement in education mediated by the soundness of the local authority.

\begin{tabular}{|c|c|c|c|c|c|}
\hline \multirow[b]{2}{*}{ Moderating Variable } & \multicolumn{4}{|c|}{ Internal Dimensions of Local Authorities' Involvement in Education } & \multirow{2}{*}{$\begin{array}{c}\text { Overall } \\
\text { Involvement } \\
\text { in } \\
\text { Education }\end{array}$} \\
\hline & $\begin{array}{l}\text { Direct Hiring of } \\
\text { Teachers }\end{array}$ & $\begin{array}{c}\text { Designation of } \\
\text { School } \\
\text { Catchment Areas }\end{array}$ & $\begin{array}{l}\text { Introducing New } \\
\text { Curricula }\end{array}$ & $\begin{array}{l}\text { Opening New } \\
\text { Schools }\end{array}$ & \\
\hline Size & N.S. & N.S. & N.S. & N.S. & N.S. \\
\hline Socioeconomic status & *(Model 1) & N.S. & $(*)$ (Model 7) & N.S. & N.S. \\
\hline Central/peripheral status & N.S. & N.S. & N.S. & N.S. & N.S. \\
\hline Financial strength & *(Model 2) & *(Model 5) & N.S. & N.S. & N.S. \\
\hline Overall soundness & *(Model 3) & *(Model 6) & N.S. & N.S. & * (Model 9) \\
\hline
\end{tabular}

${ }^{*}=p<0.05 ;\left(^{*}\right)=p<0.05$ yet findings oppose our hypothesis; N.S. = Not Significant. 
Table 3. Hierarchical regression (standardized coefficients) for transformational leadership predicting local authorities' involvement in education moderated by the soundness of the local authority.

\begin{tabular}{|c|c|c|c|c|c|c|c|c|c|c|c|c|c|c|c|c|c|c|}
\hline \multirow[b]{4}{*}{ Variables } & \multicolumn{14}{|c|}{ Internal Dimensions of Local Authorities' Involvement in Education } & \multirow{2}{*}{\multicolumn{4}{|c|}{$\begin{array}{l}\text { Overall Involvement in } \\
\text { Education }\end{array}$}} \\
\hline & \multicolumn{6}{|c|}{ Opening New Schools } & \multicolumn{6}{|c|}{ Introducing New Curricula } & \multirow{2}{*}{\multicolumn{2}{|c|}{$\begin{array}{c}\begin{array}{c}\text { Designation of } \\
\text { School } \\
\text { Catchment } \\
\text { Areas }\end{array} \\
\text { Model } 7\end{array}$}} & & & & \\
\hline & \multicolumn{2}{|c|}{ Model 1} & \multicolumn{2}{|c|}{ Model 2} & \multicolumn{2}{|c|}{ Model 3} & \multicolumn{2}{|c|}{ Model 4} & \multicolumn{2}{|c|}{ Model 5} & \multicolumn{2}{|c|}{ Model 6} & & & \multicolumn{2}{|c|}{ Model 8} & \multicolumn{2}{|c|}{ Model 9} \\
\hline & $\begin{array}{c}\text { Step1 } \\
(\beta)\end{array}$ & $\begin{array}{c}\text { Step2 } \\
(\beta)\end{array}$ & $\begin{array}{l}\text { Step1 } \\
(\beta)\end{array}$ & $\begin{array}{c}\text { Step2 } \\
(\beta)\end{array}$ & $\begin{array}{c}\text { Step1 } \\
(\beta)\end{array}$ & $\begin{array}{c}\text { Step2 } \\
(\beta)\end{array}$ & $\begin{array}{c}\text { Step1 } \\
(\beta)\end{array}$ & $\begin{array}{c}\text { Step2 } \\
(\beta)\end{array}$ & $\begin{array}{c}\text { Step1 } \\
(\beta)\end{array}$ & $\begin{array}{c}\text { Step2 } \\
(\beta)\end{array}$ & $\begin{array}{c}\text { Step1 } \\
(\beta)\end{array}$ & $\begin{array}{c}\text { Step2 } \\
(\beta)\end{array}$ & $\begin{array}{c}\text { Step1 } \\
(\beta)\end{array}$ & $\begin{array}{c}\text { Step2 } \\
(\beta)\end{array}$ & $\begin{array}{c}\text { Step1 } \\
(\beta)\end{array}$ & $\begin{array}{c}\text { Step2 } \\
(\beta)\end{array}$ & $\begin{array}{c}\text { Step1 } \\
(\beta)\end{array}$ & $\begin{array}{c}\text { Step2 } \\
(\beta)\end{array}$ \\
\hline TL & 0.02 & 0.25 & -0.04 & -0.17 & 0.02 & 0.03 & 0.14 & 0.05 & 0.14 & 0.09 & 0.13 & 0.11 & 0.03 & -0.05 & -0.02 & -0.05 & -0.04 & -0.05 \\
\hline Soc-Eco & -0.24 & $-0.30 *$ & & & & & & & & & & & -0.15 & -0.15 & & & & \\
\hline TL X Soc-Eco & & $0.46^{* *}$ & & & & & & & & & & & & $-0.32 * *$ & & & & \\
\hline $\begin{array}{l}\text { National (Jewish) } \\
\text { majority }\end{array}$ & & & & & & & 0.19 & 0.17 & & & & & & & 0.10 & 0.09 & & \\
\hline $\begin{array}{l}\text { TL X National } \\
\text { majority }\end{array}$ & & & & & & & & $0.31 * *$ & & & & & & & & $0.12 *$ & & \\
\hline $\begin{array}{l}\text { Financial } \\
\text { strength }\end{array}$ & & & -0.23 & -0.22 & & & & & -0.03 & -0.01 & & & & & & & & \\
\hline $\begin{array}{l}\text { TL X Financial } \\
\text { strength }\end{array}$ & & & & $0.31 *$ & & & & & & $0.23 *$ & & & & & & & & \\
\hline $\begin{array}{c}\text { Overall } \\
\text { soundness }\end{array}$ & & & & & 0.01 & -0.06 & & & & & 15.0 & 0.10 & & & & & 0.27 * & 0.24 * \\
\hline $\begin{array}{l}\text { TL X Overall } \\
\text { soundness }\end{array}$ & & & & & & $0.33^{* *}$ & & & & & & $0.35^{* *}$ & & & & & & $0.23 *$ \\
\hline $\mathrm{R}^{2}$ & 0.06 & 0.21 & 0.05 & 0.13 & 0.00 & 0.10 & 0.06 & 0.15 & 0.02 & 0.07 & 0.04 & 0.16 & 0.02 & 0.12 & 0.01 & 0.05 & 0.07 & 0.12 \\
\hline Adjusted $\mathrm{R}^{2}$ & 0.02 & 0.17 & 0.01 & 0.08 & -0.04 & 0.05 & 0.03 & 0.12 & -0.01 & 0.03 & 0.02 & 0.13 & 0 & 0.09 & -0.1 & 0.02 & 0.05 & 0.09 \\
\hline$\Delta \mathrm{R}^{2}$ & - & $0.16^{* *}$ & - & $0.08^{*}$ & - & $0.1 *$ & - & $0.09 * *$ & - & $0.05 *$ & - & $0.21^{* * *}$ & - & $0.09 * *$ & - & 0.04 & - & 0.05 * \\
\hline F & 1.51 & $4.49 * *$ & 1.32 & 2.43 & 0.01 & 1.98 & 2.42 & $4.74 * *$ & 0.78 & 1.90 & 1.76 & $5.28 * *$ & 1.05 & $3.90 *$ & 0.42 & 1.58 & $3.42 *$ & $4.02 * *$ \\
\hline
\end{tabular}


Model 1: Interaction effect of socio-economic status on the relationship between transformational leadership and opening new schools

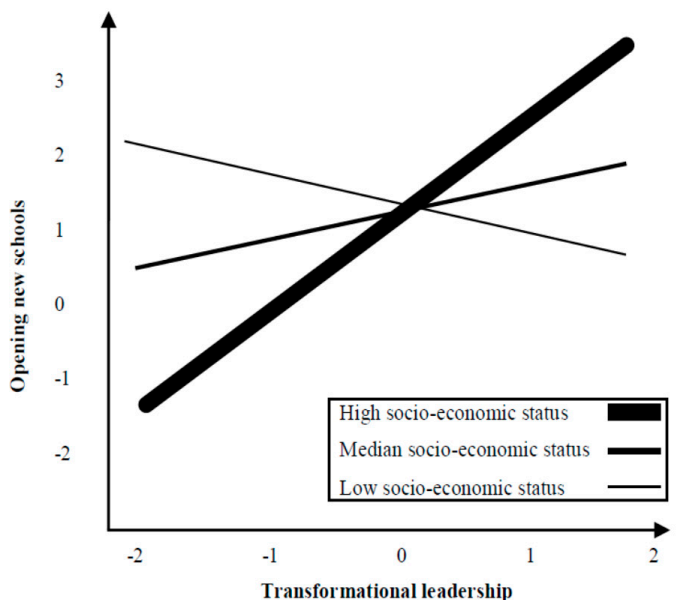

Model 2: Interaction effect of financial strength on the relationship between transformational leadership and opening new schools

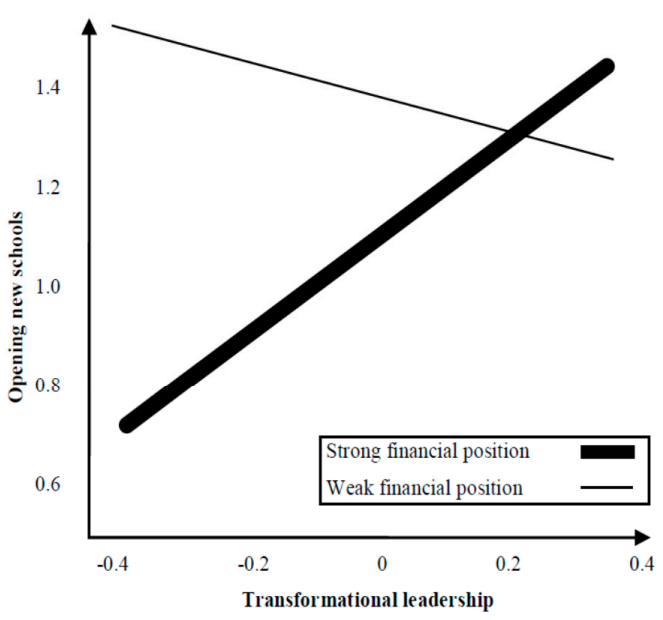

Model 3: Interaction effect of overall soundness on the relationship between transformational leadership and opent

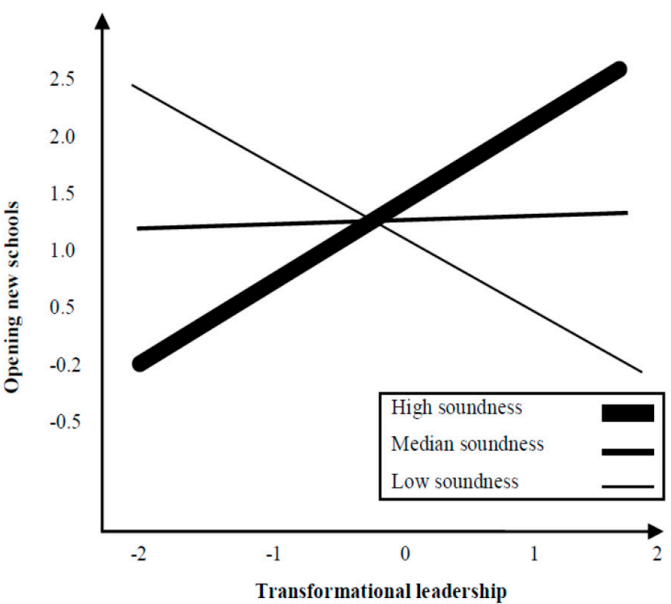

Model 4: Interaction effect of national majority on the relationship between transformational leadership and introducing new curricula

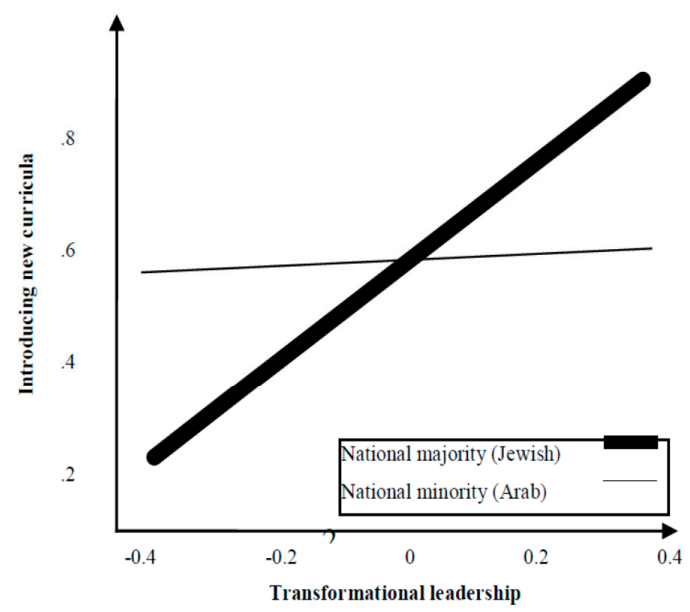

Figure 2. Cont.
Model 5: Interaction effect of financial strength on the relationship

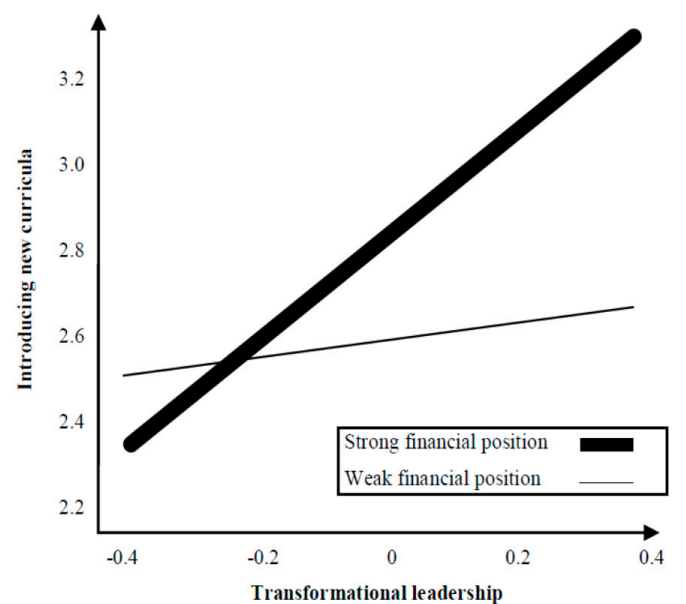

Model 6: Interaction effect of overall soundness on the relationship between transformational leadership and introducing new curricula

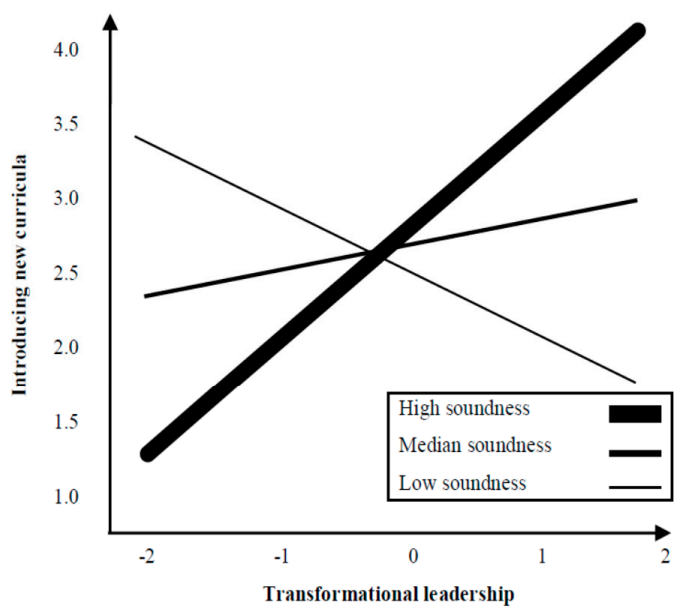


Model 7: Interaction effect of socio-economic status on the relationship between relationship between transformational leadership and designation of school catchment areas

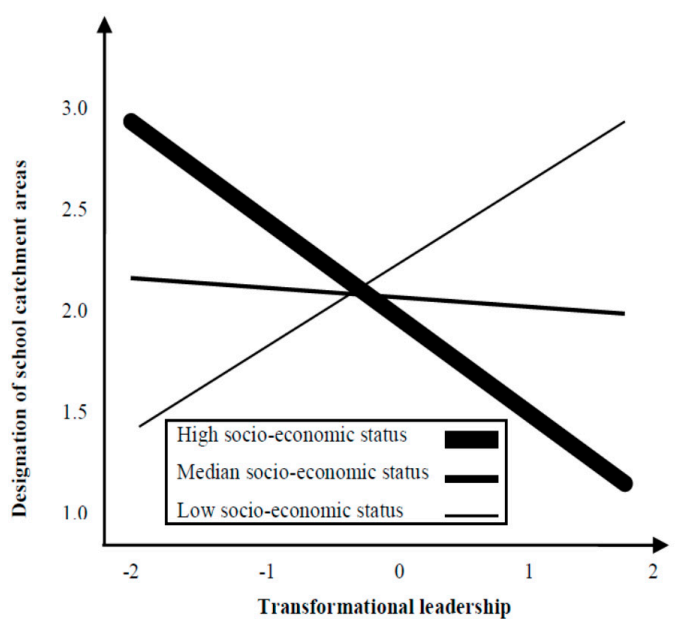

Model 8: Interaction effect of national majority on the relationship between transformational leadership and overall involvement in education

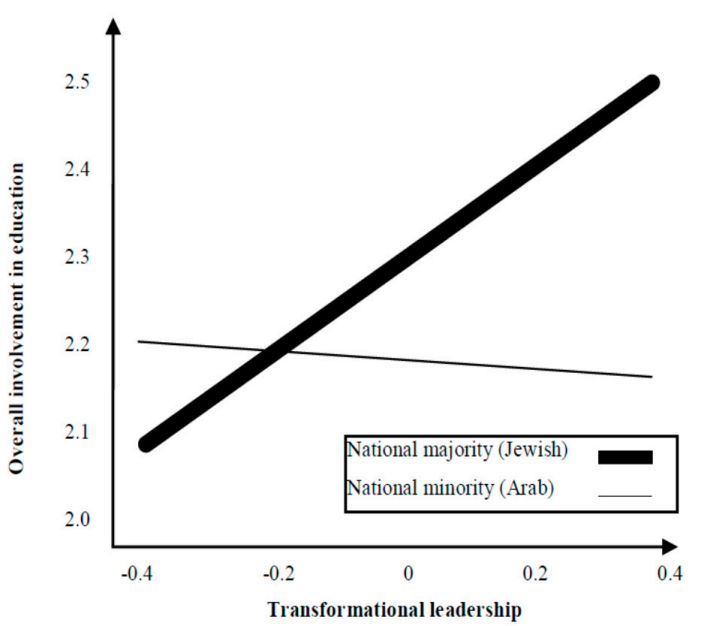

Model 9: Interaction effect of overall soundness on the transformational leadership and overall involvement in education

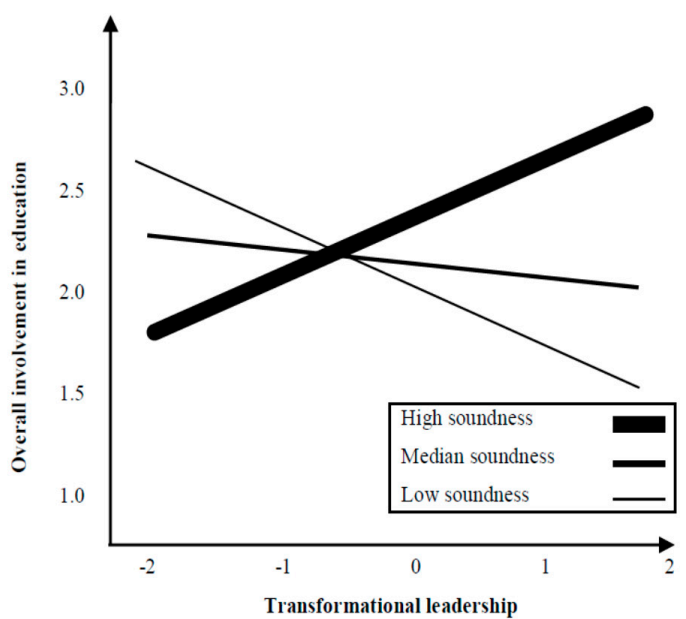

Figure 2. Interactive effects of the moderating variables on the relationship between transformational leadership and local authorities' involvement in education. 


\section{Discussion and Conclusions}

Stone [55] and Marschall and Shah [67] emphasize the importance of strong local leadership-armed with vision, an ability to build personal relationships, and savoring intellectual challenge [16]—for the success of educational reforms. Building on this contention, Shields $[33,34]$ underscores that understanding the educational context and awareness of the social context in which leadership operates within organizations is of the utmost importance. Transformative leadership, the argument goes, inextricably links education and educational leadership, resulting in an inclusive, socially just, and academically successful educational system.

We found some support for this notion. Under some conditions, transformational leadership on the part of mayors or the heads of local education departments is associated with greater involvement of local authorities in setting or implementing local education policies. Specifically, these relationships seem to hold in stable, well-off local authorities, as opposed to those that are weaker socially and financially (the one exception will be discussed below). Thus, similar to Marks and Printy [23], who conclude that in education, transformational leadership is necessary but insufficient for maximizing school performance, we present evidence for the boundaries of educational transformational leadership in educational governance. We defined educational governance as the systems and standards through which organizations control their educational activities and demonstrate accountability for the continuous improvement of educational quality and performance [68].

In recent decades, the comprehensive effects of neoliberalism have seen many public services transferred from the central government's executive branches to other bodies, among them local authorities [2]. This development reflects the trend of applying the concepts of the market economy to the relationship between citizens and the government, along with efforts to imbue public services with the values of transparency and cooperation. However, in the case of Israel [69], a neoliberal economy does not necessarily lead to substantial decentralization. Furthermore, it combines neoliberalism with many traits of centralization. These concepts reverberate throughout the literature on the subject of new localism, and they are also prevalent in studies on leadership. Clearly, new localism functions most effectively under the direction of a transformational leader, one who inspires others to pursue a shared goal, thus transforming followers into partners $[16,18]$ and increasing social capital $[6,20,29]$. Against this backdrop, education is one area of public services that is subject to frequent change, and specifically, to decentralization on the one hand and public involvement on the other.

Hypothesis 1, which expected a direct positive relationship between transformational leadership and the local authority's involvement in education, was not confirmed. There are several implications of rejecting this hypothesis. First, the transformational leadership alone of one or a few local political policymakers or educational leaders is not sufficient for transforming local education. Second, other stakeholders such as the central government should be enlisted to promote other structural conditions, above and beyond transformational leadership. Third, in the era of local governance and new localism, stakeholders such as the community, parents, teachers and principals cannot expect local leaders alone to undertake educational reform. In order for it to succeed, they must join forces with these leaders.

However, contrary to the first hypothesis, we did find support for Hypothesis 2 about the soundness of a local authority moderating the relationship between transformational leadership and the local authority's involvement in education. Confirmation for this hypothesis came with regard to two particular components: the opening of new schools and the introduction of new curricula. This finding accords with Daly and Finnegan [30] and Reckhow [41], who note that the success of educational reforms is based primarily related to civic capacity, local collaboration and the ability to recruit authentic, committed and constructive local forces. The result also accords with Beeri [70], who reports that, in the spirit of neoliberalism, the Israeli central government tends to treat local authorities as a business entity rather than a political entity. This approach favors sound local authorities and increases spatial inequality. 
The interviewees also noted that the changes regarding the involvement of local authorities in education are not uniform. They depend on the local authority's characteristics and attributes. Some of them pointed to the city of Tel Aviv, the second largest city in Israel and its wealthiest, as a leading example. The city has a great deal of independence in the area of education, and has launched many initiatives that other local authorities copy. Some of the other examples that the interviewees cited seemed to indicate that the soundness of the local authority might be a pre-condition for independence in the area of local education, accountability and governability. In contrast, they claimed that weak local authorities are more likely to rely on the Ministry of Education, and avoid making decisions.

As regards the relatively weaker local authorities, we assumed that there would be a weak relationship or no relationship at all between a transformational leadership style and involvement in education. However, our findings revealed an inverse correlation in some cases. In generally weaker local authorities (and particularly those that scored low on socioeconomic status), a transformational leadership style seems to be associated with the avoidance of involvement in educational matters, measured in terms of opening new schools, introducing new curricula, and overall involvement in education. This finding may relate to national constraints put on weak local authorities that result in local policymakers having less autonomy [71] and more checks on them. Both of these factors may mean that weaker local authorities are not receptive to transformational leaders [72].

However, another explanation for this finding may relate to what it means to be a transformational leader in a relatively underprivileged community. Transformational leadership combines the ability to inspire others to realize a comprehensive vision and sensitivity to the entire gamut of people's needs, from the basic to the most complex [16,18]. As Maslow [73] recognized in his hierarchy of needs, issues of content and values can be addressed only after basic needs are completely satisfied-something that is as true for communities as for individuals [20]. Schools and the curricula taught in them can develop and preserve a community's identity. Those who support the concept of new localism in education emphasize the important role of such systems in fortifying the common foundations that keep the community united $[26,28]$. Nevertheless, these systems are based on an infrastructure that must be built and maintained, textbooks and supplies that must be purchased, teachers and other staff whose salaries must be paid-all requiring resources that less privileged communities might be hard-pressed to find. It is possible that transformational leaders, weighing the resources available to them against the local population's needs, find it preferable to leave core pedagogical issues in the hands of the central government.

It is also possible that in weak municipalities, the ability of policymakers to recruit partnerships from within the community is relatively limited. They may prefer to rely on external forces, including the various resources provided by the central government [29]. This conclusion accords with Reckhow's [41] observation that not all cities are fortunate enough to develop civic capacity, in part due to the failure of the mayor to create a coalition of very engaged supporters. Likewise, transformational leadership that is attentive to the desires of the people would also be aware of residents' priorities. A sensitive leader would not push the local authority to deal prematurely with issues of educational content and values when more basic educational needs are not yet being met.

In this vein, Essuman and Akyeampong [36] investigated a closely related topic, namely residents' participation in decision making under a policy of decentralizing education in Ghana. These researchers found that in weak, village-based local authorities, after a decade the residents regarded involvement as a waste of time. They purposely avoided it, in a manner that expressed-albeit implicitly—their discontent with the transfer of responsibility to citizens. The provincial government was invited to return and take control of education. It is possible that in Israel, too, local leaders in weaker local authorities were taken aback by the transfer of certain responsibilities, which they would have preferred to leave in the hands of the central government.

One surprising finding was that in relatively weak local authorities, there was a direct relationship between a transformational leadership style and involvement in the designation of school catchment areas. This finding may suggest that education-related policies are on the agenda of leaders even in 
weaker local authorities, but only to the extent that these policies can meet specific needs of the local community. For instance, parents want their children to go to the better schools, which means they do not want the catchment areas. Presumably, local leaders would have an interest in controlling these boundaries. Another explanation may be that in comparison with other educational policies, the designation of school catchment areas requires fewer material and human capital resources, which makes this path an opportunity for transformational leaders in relatively weak local authorities.

Finally, the statistically significant findings in the current study may indicate the existence of a cyclical trend. Sound local authorities offer fertile ground for developing localism, the unfolding of which encourages involvement in education, which then strengthens new localism. It appears that activities initiated in order to increase community involvement are likely to have a nurturing effect on localism. A combination of initiatives for civic empowerment and transformational leadership may lead relatively weaker local authorities to increase their involvement in education, which-following this cyclical process-may strengthen the progress towards localism in these areas as well. In this vein, Gal-Arieli et al. [59] raised the concern that new localism would result in increased gaps between local authorities.

All in all, there is no "one size fits all" for all aspects of new localism-i.e., central regulation towards local government, local policy, local leadership, and civic participation. Accordingly, policymakers, local leaders and residents must fit themselves to the blurred boundaries of new localism and collaborate towards better education.

The current study has a number of limitations. First, the research instrument used questioned respondents about only four aspects of involvement in education. However, involvement in education is a complex variable with many possible manifestations, some of which may not have been captured by the questionnaire. Another limitation is the use of self-report data about the transformational leadership of municipal leaders. We must consider the well-known possibility of self-report bias and the possibility that these leaders may have a different perception of education than those who work in schools. Future studies should attempt to extend the current work using more objective or at least additional sources for such data. Finally, as this is a panel survey and the data are not longitudinal, no causal relationships can be drawn.

Nevertheless, our study can shed light on the connection between the notion of new localism and leadership style, and on the effects of this relationship on the formulation of public policies. It may also open up an additional avenue of research, focused on the reciprocal influences of the type identified above.

Author Contributions: N.G.-A., I.B., E.V.-G. and A.R. designed, conceptualized and proposed the model, reviewed and edited the paper and approved the final manuscript. N.G.-A. operationalized the survey and data analysis and wrote the paper. All authors have read and agreed to the published version of the manuscript.

Funding: This research received no external funding.

Conflicts of Interest: The authors declare no conflict of interest.

\section{References}

1. Koppich, J.E.; Esch, C. Grabbing the Brass Ring. Educ. Policy 2012, 26, 79-95. [CrossRef]

2. Galey, S. Education Politics and Policy: Emerging Institutions, Interests, and Ideas. Policy Stud. J. 2015, 43, S12-S39. [CrossRef]

3. Rhodes, R.A.W. The new governance: Governing without government. Political Stud. 1996, 44, 652-667. [CrossRef]

4. Greer, A.; Hoggett, P. Public policies, private strategies and local public spending bodies. Public Adm. 1999, 77, 235-256. [CrossRef]

5. Bovaird, T.; Löffler, E. Moving from excellence models of local service delivery to benchmarking 'good local governance'. Int. Rev. Adm. Sci. 2002, 68, 9-24. [CrossRef]

6. Bagley, C.; Hillyard, S. Rural schools, social capital and the Big Society: A theoretical and empirical exposition. Br. Educ. Res. J. 2014, 40, 63-78. [CrossRef] 
7. Goodson, I. The educational researcher as a Public Intellectual. Br. Educ. Res. J. 1999, 25, 277-297. [CrossRef]

8. Jones, T.; Ormston, C. Localism and accountability in a post-collaborative era: Where does it leave the community right to challenge? Local Gov. Stud. 2014, 40, 141. [CrossRef]

9. Park, H.M.; Perry, J.L. The transformation of governance: Who are the new public servants and what difference does it make for democratic governance? Am. Rev. Public Adm. 2013, 43, 26-49. [CrossRef]

10. Sandfort, J.; Selden, S.C.; Sowa, J.E. Do government tools influence organizational performance? Examining their implementation in early childhood education. Am. Rev. Public Adm. 2008, 38, 412-438. [CrossRef]

11. Correy, D.; Stoker, G. New Localism: Refashioning the Centre-Local Relationship; New Local Government Network: London, UK, 2002.

12. Waddock, S. Reframing and Transforming Economics around Life. Sustainability 2020, 12, 7553. [CrossRef]

13. Stone-Johnson, C. Responsible leadership. Educ. Adm. Q. 2014, 50, 645-674. [CrossRef]

14. Rhodes, C.; Brundrett, M. Leadership development and school improvement. Educ. Rev. 2009, 61, 361-374. [CrossRef]

15. Hicks, T. Partisan governance and policy implementation: The politics of academy conversion amongst English schools. Public Adm. 2014, 92, 995-1016. [CrossRef]

16. Bass, B.M. Leadership and Performance Beyond Expectation; Free Press: New York, NY, USA, 1985.

17. Bass, B.M.; Avolio, B.J. Improving Organizational Effectiveness through Transformational Leadership; Sage: Thousand Oaks, CA, USA, 1994.

18. Burns, J.M. Leadership; Harper \& Row: New York, NY, USA, 1978.

19. Mathews, D. Why we need to change our concept of community leadership. Community Educ. J. 1996, 23, 9-18.

20. Putnam, R.D. Bowling alone: America's declining social capital. J. Democr. 1995, 6, 65-78. [CrossRef]

21. Putnam, R. Making Democracy Work: Civic Traditions in Modern Italy; Princeton University Press: Princeton, NJ, USA, 1993.

22. Johnstone, S.; Robison, R.A.V.; Manning, R. Delivering Social Sustainability Outcomes in New Communities: The Role of the Elected Councillor. Sustainability 2013, 5, 4920-4948. [CrossRef]

23. Leithwood, K.; Jantzi, D. A review of transformational school leadership research 1996-2005. Leadersh. Policy Sch. 2005, 4, 177-199. [CrossRef]

24. Marks, H.M.; Printy, S.M. Principal leadership and school performance: An integration of transformational and instructional leadership. Educ. Adm. Q. 2003, 39, 370-397. [CrossRef]

25. Crowson, R.L.; Goldring, E.B. The new localism: Re-examining issues of neighborhood and community in public education. Yearb. Natl. Soc. Study Educ. 2009, 108, 1-24.

26. Hodgson, A.; Spours, K. Three version of "localism": Implications for upper secondary education and lifelong learning in the UK. J. Educ. Policy 2012, 27, 193-210. [CrossRef]

27. Reynolds, L. Local Governments and Regional Governance. Urban Lawyer 2007, 39, 483-528.

28. Wei $\beta$, W. Local Government Education Policy: Developments Concepts and Perspectives. 2009. Available online: http://www.difu.de/node.6861 (accessed on 10 December 2012).

29. Chen, L.; Zheng, W.; Yang, B.; Bai, S. Transformational leadership, social capital and organizational innovation. Leadersh. Organ. Dev. J. 2016, 37, 843-859. [CrossRef]

30. Daly, A.J.; Finnegan, K.S. Mind the gap: Organizational learning and improvement in an underperforming urban system. Am. J. Educ. 2012, 119, 41-71.

31. Gunter, H. Leaders and Leadership in Education; Paul Chapman: London, UK, 2001.

32. Bieneman, P.D. Transformative leadership: The exercise of agency in educational leadership. Counterpoints 2011, 409, 221-237.

33. Shields, C.M. Transformative leadership: Working for equity in diverse contexts. Educ. Adm. Q. 2010, 46, 558-589. [CrossRef]

34. Shields, C.M. Transformative Leadership in Education: Equitable and Socially Just Change in an Uncertain and Complex World; Routledge: Abingdon-on-Thames, UK, 2017.

35. Spillane, J.P.; Hopkins, M.; Sweet, T.M. Intra-and interschool interactions about instruction: Exploring the conditions for social capital development. Am. J. Educ. 2015, 122, 71-110. [CrossRef]

36. Essuman, A.; Akyeampong, K. Decentralisation policy and practice in Ghana: The promise and reality of community participation in education in rural communities. J. Educ. Policy 2011, 26, 513-527. [CrossRef] 
37. Vidovich, L. Global-national-local dynamics in policy processes: A case of 'quality' policy in higher education. Br. J. Sociol. Educ. 2004, 25, 341-354. [CrossRef]

38. Coaffee, J. New localism and the management of regeneration. Int. J. Public Sector Manag. 2006, 18, $108-113$. [CrossRef]

39. Giddens, A. The Third Way. The Renewal of Social Democracy; Policy Press: Cambridge, UK, 1998.

40. De Vries, M.S. The rise and fall of decentralization: A comparative analysis of arguments and practices in European countries. Eur. J. Political Res. 2000, 38, 193-224. [CrossRef]

41. Reckhow, S. Follow the Money: How Foundation Dollars Change Public School Politics; Oxford University Press: Oxford, UK, 2012.

42. Collins, M. Local solutions for national challenges? Exploring local solutions through the case of a national succession planning strategy. Educ. Manag. Adm. Leadersh. 2013, 41, 658-673. [CrossRef]

43. Lingard, B.; Sellar, S.; Savage, G.C. Re-articulating social justice as equity in schooling policy: The effects of testing and data infrastructures. Br. J. Sociol. Educ. 2014, 35, 710-730. [CrossRef]

44. Balfanz, J.; Andrekopoulos, W.; Hertz, A.; Kilman, C.T. Closing the Implementation Gap: Leveraging City Year and National Service as a New Human Capital Strategy to Transform Low-Performing Schools. New York 2012, NY City Year. Available online: https://www.cityyear.org/wp-content/uploads/2019/10/ ClosingtheImplementationGap.pdf (accessed on 11 November 2020).

45. Compulsory Learning Law. No. 5709-1949. 1949. (In Hebrew)

46. Gibton, D. Post-2000 law-based educational governance in Israel: From equality to diversity? Educ. Manag. Adm. Leadersh. 2011, 39, 434-454. [CrossRef]

47. Vigoda-Gadot, E.; Dryzin-Amit, Y. Organizational politics leadership and performance in modern public worksites: A theoretical framework. In Handbook of Organizational Politics (3-15); Vigoda-Gadot, E., Drory, A., Eds.; Edward Elgar Publishing: Cheltenham, UK, 2006.

48. Gupta, V.K.; Huang, R.; Yayla, A.A. Social capital, collective transformational leadership, and performance: A resource-based view of self-managed teams. J. Manag. Issues 2011, 23, 31-45.

49. Moolenaar, N.M.; Sleegers, P.J.; Daly, A.J. Teaming up: Linking collaboration networks, collective efficacy, and student achievement. Teach. Teach. Educ. 2012, 28, 251-262. [CrossRef]

50. Robinson, V.M.; Lloyd, C.A.; Rowe, K.J. The impact of leadership on student outcomes: An analysis of the differential effects of leadership types. Educ. Adm. Q. 2008, 44, 635-674. [CrossRef]

51. Kerr, K.; Dyson, A.; Gallannaugh, F. Conceptualising school-community relations in disadvantaged neighbourhoods: Mapping the literature. Educ. Res. 2016, 58, 265-282. [CrossRef]

52. Gumus, S.; Bellibas, M.S.; Esen, M.; Gumus, E. A systematic review of studies on leadership models in educational research from 1980 to 2014. Educ. Manag. Adm. Leadersh. 2018, 46, 25-48. [CrossRef]

53. Heck, R.H.; Larsen, T.J.; Marcoulides, G.A. Instructional leadership and school achievement: Validation of a causal model. Educ. Adm. Q. 1990, 26, 94-125. [CrossRef]

54. Male, T.; Palaiologou, I. Pedagogical leadership in the 21st century: Evidence from the field. Educational Manag. Adm. Leadersh. 2015, 43, 214-231. [CrossRef]

55. Stone, C. Civic capacity and urban education. Urban Aff. Rev. 2001, 36, 595-619. [CrossRef]

56. Grant, C.A.; Floch Arcello, A.; Konrad, A.M.; Swenson, M.C. Fighting for the 'right to the city': Examining spatial injustice in Chicago public school closings. Br. J. Sociol. Educ. 2014, 35, 670-687. [CrossRef]

57. Orfield, G. Tenth Annual Brown Lecture in Education Research. A new civil rights agenda for American education. Educ. Res. 2014, 43-46, 273-292. [CrossRef]

58. Schmidt, W.H.; Burroughs, N.A.; Zoido, P.; Houang, R.T. The role of schooling in perpetuating educational inequality: An international perspective. Educ. Res. 2015, 44, 371-386. [CrossRef]

59. Gal-Arieli, N.; Beeri, I.; Vigoda-Gadot, E.; Reichman, A. New localism or fuzzy centralism: Policymakers' perceptions of public education and involvement in education. Local Gov. Stud. 2017, 43, 598-620. [CrossRef]

60. Postholm, M.B. The school leader's role in school-based development. Educ. Res. 2019, 61, 437-450. [CrossRef]

61. Beeri, I.; Navot, D. Local Political Corruption: Potential Structural Malfunctions at the Central-Local, Local-Local and Intra-Local Levels. Public Manag. Rev. 2013, 15, 712-739. [CrossRef]

62. Beeri, I.; Yuval, F. New Localism and Neutralizing Local Government: Has Anyone Bothered Asking the Public for Its Opinion? J. Public Adm. Res. Theory 2015, 25, 623-653. [CrossRef] 
63. Levi, Y. Relationship between central government and local government: Characteristics and political structures. In The Local Authority_Between the State, the Community, and the Market Economy; Levi, Y., Sarig, E., Eds.; The Open University: Raanana, Israel, 2016. (In Hebrew)

64. Dahan, Y.; Yona, Y. The Dovrat committee report: On the neo-liberal revolution in education. Theory Crit. 2005, 27, 11-38. (In Hebrew)

65. Fowles, J.; Butler, J.S.; Cowen, J.M.; Streams, M.E.; Toma, E.F. Public employee quality in a geographic context: A study of rural teachers. Am. Rev. Public Adm. 2014, 44, 503-521. [CrossRef]

66. Wallner, J. Legitimacy and public policy: Seeing beyond effectiveness, efficiency and performance. Policy Stud. J. 2008, 36, 421-443. [CrossRef]

67. Marschall, M.; Shah, P. Keeping policy churn off the agenda: Urban education and civic capacity. Policy Stud. J. 2005, 33, 161-180. [CrossRef]

68. Sacre, H.; Hallit, S.; Hajj, A.; Zeenny, R.M.; Sili, G.; Salameh, P. The pharmacy profession in a developing country: Challenges and suggested governance solutions in Lebanon. J. Res. Pharm. Pract. 2019, 8, 39. [PubMed]

69. Eshel, S.; Hananel, R. Centralization neoliberalism, and housing policy central-local government relations and residential development in Israel. Environ. Plan. C Politics Space 2019, 37, 237-255. [CrossRef]

70. Beeri, I. Lack of reform in Israeli local government and its impact on modern developments in public management. Public Manag. Rev. 2020, 1-13. Available online: https://doi-org.ezproxy.haifa.ac.il/10.1080/ 14719037.2020.1823138 (accessed on 11 November 2020). [CrossRef]

71. Beeri, I. Direct administration of failing local authorities: Democratic deficit or effective bureaucracy? Public Money Manag. 2020, 33, 137-144. [CrossRef]

72. Shamir, B.; Howell, J.M. Organizational and contextual influences on the emergence and effectiveness of charismatic leadership. Leadersh. Q. 1999, 10, 257-283. [CrossRef]

73. Maslow, A. Motivation and Personality; Longman: New York, NY, USA, 1954.

Publisher's Note: MDPI stays neutral with regard to jurisdictional claims in published maps and institutional affiliations.

(C) 2020 by the authors. Licensee MDPI, Basel, Switzerland. This article is an open access article distributed under the terms and conditions of the Creative Commons Attribution (CC BY) license (http://creativecommons.org/licenses/by/4.0/). 